\title{
A review of the biophysical impacts of climate change in three hotspot regions in Africa and Asia
}

\author{
Garrett Kilroy
}

Received: 6 August 2013/Accepted: 12 March 2014/Published online: 30 January 2015

(C) Springer-Verlag Berlin Heidelberg 2014

\begin{abstract}
A systematic review was conducted of biological and physical climate change impacts in three hotspot regions in Africa and Asia. Specifically, the review focused on identifying the nature and extent of biophysical impacts in semi-arid zones, mega-deltas and glacial-fed river basins. In total 139 , peer-reviewed articles were reviewed, with a steady increase in relevant articles reported since 2006. Publications on the South Asian glacial-fed river basins were the most numerous followed by semi-arid areas and then deltas, with Central Asia and some African countries being the most under represented. The nature and extent of impacts varied for each hotspot area and were largely determined by the geographical context and intrinsic characteristics of each region. River basin publications were dominated by impacts concerning hydrology, highlighting the importance of glacial-fed water resources to downstream populations. Semi-arid regions were dominated by impacts to climate processes and impacts to livestock and vegetation highlighting the importance of rainfall to the ecosystems and the livelihoods of communities in these regions. In contrast, delta studies were dominated by a focus on hazards, predominantly coastal inundation, reflecting the concentration of populations and assets in these areas. Uncertainties associated with the biophysical impacts on these regions under a changing climate are documented and represent key knowledge gaps. Common information gaps for all hotspot regions were the
\end{abstract}

Electronic supplementary material The online version of this article (doi:10.1007/s10113-014-0709-6) contains supplementary material, which is available to authorized users.

G. Kilroy $(\bowtie)$

Department of Geology, School of Natural Sciences,

Trinity College Dublin, Dublin 2, Ireland

e-mail: garrettkilroy@gmail.com need for improved hydro-meteorological monitoring systems. The development of climate change adaptation strategies and policies should be supported by a sound knowledge and understanding of the full range of biophysical impacts, which are characteristic to each geographical location.

Keywords Biological and physical impacts - Climate change $\cdot$ Semi-arid $\cdot$ Mega-deltas $\cdot$ Glacial-fed river basins

\section{Introduction}

The IPCC Fourth Assessment Report (AR4) (IPCC 2007) identified low-lying deltas in Africa and Asia (Nicholls et al. 2007), glacial-fed river basins in South Asia (Cruz et al. 2007) and semi-arid regions of Africa, South and Central Asia (Boko et al. 2007; Cruz et al. 2007; Kundzewicz et al. 2007) as particularly vulnerable to the impacts of climate change. These climate change 'hotspots' and their people have complex and overlapping vulnerabilities with their geographical location and exposure to climatic pressures being an intrinsic element of these vulnerabilities (De Souza et al. 2015). The series of papers for this special issue concern climate change adaptation in these hotspot areas, which are the focus of a new research programme called the Collaborative Adaptation Research Initiative in Africa and Asia (CARIAA) being developed by the United Kingdom's Department for International Development and Canada's International Development Research Centre. This paper forms part of this special issue, identifying and characterising the state of knowledge of biophysical impacts from climate change in these hotspot areas (for a map of these areas, see Ford et al. 2014). 
Physical and biological systems can be affected by both climate and non-climate drivers (Rosenzweig and Neofotis 2013). A common link in all three hotspot areas is the manner in which climate and non-climate drivers interact to generate pressures and impacts on these different environments with consequent impacts for communities and their livelihoods. The degradation of these environments, of their ecosystems and their services result in multiple human impacts including changes to primary productivity affecting food security, disruption of hazard regulation capacity and reduction in the availability and quality of water. It is this link between biophysical impacts and consequent impacts on vulnerable communities (see Tucker et al. 2014) who depend on these services that should ultimately drive adaptation efforts. A sound understanding of the characteristics and knowledge gaps of these biophysical impacts is therefore required. The issue of attribution of anthropogenic climate change, compared to other drivers, is important to bring about societal change in addressing these impacts (Rosenzweig et al. 2008). However, such attribution was beyond the scope of this review. The emphasis here, and main aim of this paper, is on identifying the nature and extent of observed and predicted biophysical impacts that can at least partially be attributed to climate change. To this end, a systematic review approach was undertaken to identify the nature and extent of biophysical impacts from climate change in the three-hotspot regions, their relative significance, and the key knowledge and information gaps to guide future research needs and support adaptation planning.

\section{Methodology}

Characteristics of the hotspot regions

Under the Köppen Climate Classification System, arid climate zones (including semi-arid) represent $57.2 \%$ of land area in Africa and $23.9 \%$ of land area in Asia (Peel et al. 2007). These dryland regions, with their characteristic low and highly variable precipitation and high evapotranspiration make them particularly vulnerable to global change drivers with potential impacts on the ecosystem services important for human development and well-being (Maestre et al. 2012; Bizikova et al. 2015). Increasing aridity and drought are likely to increase substantially in many developing country regions particularly those located in tropical and subtropical areas (World Bank 2012).

Densely populated deltas, particularly African and Asian ones, are key societal hotspots of coastal vulnerability, occurring where the stresses on natural systems coincide with low human adaptive capacity and high exposure (Nicholls 2007). Stresses include reduction in sediment load due to upstream dams, diversion of freshwater flows for consumptive use, groundwater and hydrocarbon abstraction, and the compounding factors of increasing and predicted eustatic sea-level rise and an intensification of tropical and extra-tropical cyclones (Ericson et al. 2006). This puts at risk the vast range of ecological services, and dependent livelihoods, provided by these deltas including nutrients for agriculture, habitat for fisheries and protection from floods.

Glacial-fed river basins in South Asia, originating in the Hindu-Kush Himalayan region and Tibetan plateau, provide goods and services to some 1.5 billion people, particularly the dependent and densely populated areas in the floodplains downstream (Singh et al. 2011; Sud et al. 2015). These 'water towers' (Bocchiola et al. 2011) help sustain downstream populations by providing water for consumptive (e.g. drinking water, irrigation) and non-consumptive uses (e.g. hydropower) as well as providing environmental flows. However, the diverse topography, young geological formations, high degree of glaciation and strong monsoon influence make these basins particularly prone to erosion/ sedimentation and natural hazards including glacial lake outburst floods (GLOF), landslide and debris flow, droughts and floods (Shrestha et al. 2010). Notwithstanding multiple uncertainties, climate change is expected to exacerbate these hazards and impact on water availability for downstream populations (Eriksson et al. 2009).

\section{Systematic review methodology}

Systematic reviews, long employed in the medical sciences, are increasingly being used to address global environmental change-related research questions (Berrang-Ford et al. 2011; Lesnikowski et al. 2011; Pearce et al. 2011; Ford et al. 2014). Berrang-Ford et al. (2015) provide a detailed examination of systematic reviews, their limitations and application to global environmental change research. They define systematic reviews as "a focused review of the literature that seeks to answer a specific research question using a set of standardised techniques and explicitly outlined methods".

This review aimed to address the following key research questions:

1. What is the range of biophysical impacts from climate change being experienced or predicted in the threehotspot regions?

2. What is the relative importance of these impacts across the hotspot regions?

3. What are the key knowledge and information gaps for these regions?

Given the breath of regions, countries and topics comprising these biophysical impacts, some restrictions were 
Table 1 Inclusion and exclusion criteria for this systematic review

\begin{tabular}{|c|c|}
\hline Included & Excluded \\
\hline $\begin{array}{l}\text { Publications dealing with impacts } \\
\text { occurring or predicted to occur } \\
\text { due, at least partially, to climate } \\
\text { change }\end{array}$ & $\begin{array}{l}\text { Publications dealing with impacts } \\
\text { from exclusively non-climatic } \\
\text { drivers }\end{array}$ \\
\hline $\begin{array}{l}\text { Publications dealing with post- } \\
\text { industrial climate change }\end{array}$ & $\begin{array}{l}\text { Publications dealing with pre- } \\
\text { industrial climate change, e.g. } \\
\text { quaternary studies }\end{array}$ \\
\hline $\begin{array}{l}\text { Publications dealing with impacts } \\
\text { occurring in at least one of the } \\
\text { three hotspot areas }\end{array}$ & $\begin{array}{l}\text { Publications dealing with impacts } \\
\text { occurring outside the three } \\
\text { hotspot areas (with the } \\
\text { exception of the Tibet } \\
\text { Autonomous Region of China) }\end{array}$ \\
\hline $\begin{array}{l}\text { Publications dealing with impacts } \\
\text { that are biophysical in nature }\end{array}$ & $\begin{array}{l}\text { Publications addressing impacts } \\
\text { in exclusively human systems } \\
\text { and publications wholly } \\
\text { addressing adaptation strategies } \\
\text { and policies }\end{array}$ \\
\hline $\begin{array}{l}\text { Publications published since } 1 \\
\text { January } 2006 \text { to } 30 \text { March } 2013\end{array}$ & Published before 2006 \\
\hline Original article or review paper & Books or book chapters \\
\hline English only & Non-english \\
\hline
\end{tabular}

required to identify a representative but manageable subset of literature. This review only used the search engine ISI Web of Knowledge (WoK), which is one of the comprehensive and widely used search engines available for analysis of interdisciplinary, peer-reviewed literature (Jasco 2005). The review focused on peer-reviewed literature documenting climate change biophysical impacts published since 2006. Literature prior to 2006 was not reviewed as this is covered by IPCC AR4 (IPCC 2007). Grey literature was not included in the analysis but was used in some cases for citation tracking to identify additional peer-reviewed literature (e.g. Singh et al. 2011; World Bank 2012; IPCC 2012). The following search terms were applied to capture each hotspot region:

- ("climate change" OR "global warming") AND

- (impact*) AND

- (delta*) OR (semiarid OR semi-arid OR steppe OR dryland*) OR (Indus OR (Ganges OR Ganga) OR Brahmaputra) OR (Himalaya* OR "Hindu Kush" OR (Karakoram OR Karakorum))

The inclusion and exclusion criteria applied to the selected documents are presented in Table 1 . The review was limited to impacts that are manifested in biophysical phenomena. This extends to the condition (or health) of ecosystems, which support human systems and how humans perceive changes to these ecosystems but not how humans exploit them or deal with changes in the condition of these ecosystems. For example, this study includes agricultural impacts from climate such as crop yields but does not include food security. Health issues were excluded except for disease-related hazards influenced by climate change. All human responses to climate change impacts are excluded, including changes in management of natural resources and adaptation/mitigation strategies, policies and practices. The search was limited to countries in Africa, Central and South Asia. One exception was a small number of publications from the Tibet Autonomous Region of China, which form the headwaters of some of the South Asian river basins.

Four steps were adopted to implement the systematic review:

1. Search of Web of Knowledge.

2. Application of inclusion and exclusion criteria to determine an initial list of documents.

3. Search of cited references from the initial list of documents to identify any additional key documents and determine the final list of documents for data extraction.

4. Data extraction based on the key research questions.

The key research questions were used to guide the extraction of data from the final group of documents that meet all selection criteria. All references retrieved from the searches were collated in Zotero, a bibliographic software package, prior to assessment against the inclusion and exclusion criteria. An Excel spread sheet was used to systematically extract data from the final list of documents and to allow some statistical analysis for graphical presentation, as per Lesnikowksi et al. (2011). Metrics extracted included the type of research undertaken (review or original research), the geographical focus (countries and hotspot addressed), the scale of analysis (local, regional/ sub-basin, ecoregion/landscape/basin), the primary climate impacts reported (key observed and projected trends), the main thematic impact category addressed (hydrology, climate, hazards, ecology and agriculture) and the specific impact sub-category examined (e.g. glacial melt, precipitation, coastal inundation, ecological shifts and crop yields). Finally, reported data or knowledge gaps in the publications were extracted to guide an exploration of future research needs in the hotspot areas.

\section{Results}

\section{General trends}

The application of these search criteria for peer-reviewed literature resulted in 1,170 records after duplicates was removed. An initial assessment of the titles and abstracts against the inclusion and exclusion criteria reduced this to 322. A subsequent more thorough assessment of this 


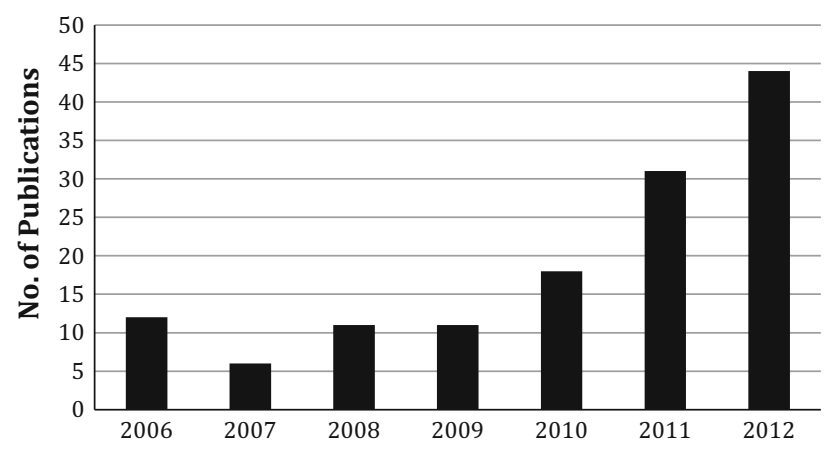

Fig. 1 Number of publications reviewed by year. Data for 2013 (six publications) are not presented as it only includes publications up until 30 March 2013

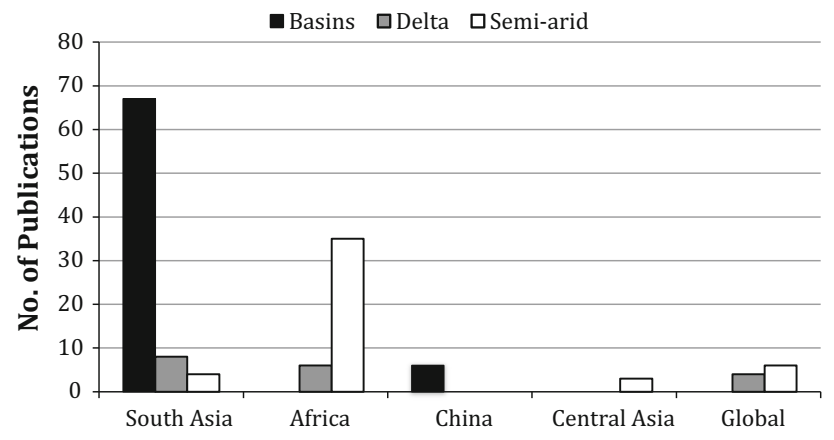

Fig. 2 Number of publications by region for each hotspot

subset, including review of the full article, reduced this number to 130 articles. Of these, 13 publications could not be sourced reducing the number of available full articles to 117. After reviewing these articles and other grey literature reviews, and in particular their cited references, an additional 22 publications were identified. This yielded a total of 139 peer-reviewed publications for data extraction-73 for river basins, 48 for semi-arid areas and 18 for deltas. These 139 publications are listed in the supplementary data.

The number of papers identified using the selection criteria for biophysical impacts of climate change in the hotspot areas has risen steadily since 2006 (Fig. 1). Just under half of the publications selected $(47 \%)$ focused on observed biophysical impacts of climate change with the remainder $(53 \%)$ involving modelled projections of future impacts. Most of the selected documents were original research journal articles with only $15 \%$ (21) being review papers. Publications were greatest in number for South Asian countries, followed by African countries, with least numbers for Central Asian countries (Fig. 2).

Figure 3 provides a summary graph of the main thematic impact categories for each hotspot region. Each

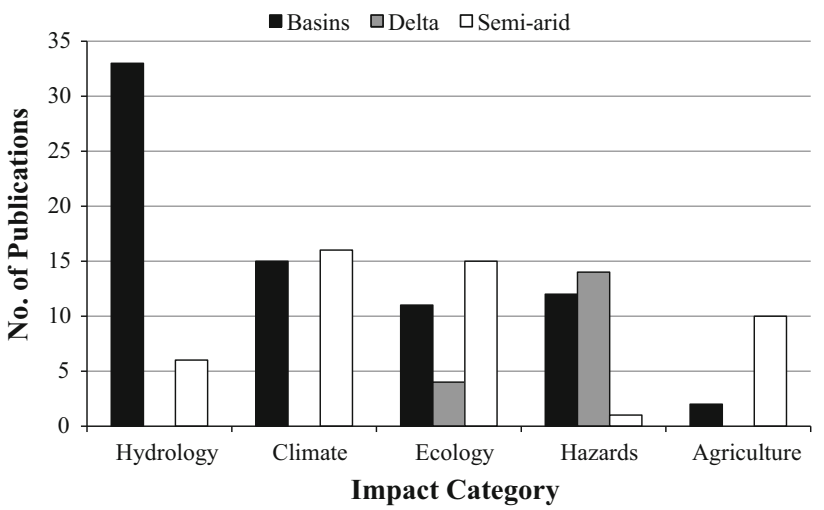

Fig. 3 Number of publications for the main biophysical impact categories

hotspot differed in the nature and extent of observed or predicted impacts. River basin publications were dominated by hydrological and climate-related impacts. Publications on deltas were limited to hazard and ecological impacts. Semi-arid publications focused mainly on climaterelated, ecological and agricultural impacts. Hydrological impacts covered a range of components of the river hydrograph including glacier and snow melting, river run-off and groundwater. Climatic studies focused on changes observed or predicted in the hotspot regions climate systems, mainly temperature and precipitation with consequential impacts for all other impact categories, e.g. drought, floods. Ecological impacts were dominated by studies on various ecological shifts across latitudinal and altitudinal gradients and phenological impacts. Studies on hazards varied for each hotspot region. Hazards in deltas focused on impacts related to sea-level rise, and in river basins mainly concerned flood impacts including glacial lake outburst floods. Hazards specific to semi-arid regions included fire, but there was also a strong emphasis on climate-related hazards such as drought, which were captured in the climate category especially in studies on temperature, precipitation and evapotranspiration. Agricultural impacts were reported mainly for the semi-arid regions dealing mostly with crop yields and livestock. Table 2 provides a more detailed characterisation of the publications for each hotpot including specific impact sub-categories, which are described in more detailed below.

\section{River basins}

The Hindu-Kush Himalaya (HKH) and Karakoram mountain region have been described as the water tower of Asia (Immerzeel et al. 2010; Bocchiola et al. 2011). This was borne out in the fact that hydrological impacts were the most common for the river basin publications (Fig. 3). The impacts on water can be broadly grouped into those concerning the cryosphere (melting glaciers, 
Table 2 Number of publications by biophysical impact categories and sub-categories

\begin{tabular}{|c|c|c|c|c|}
\hline Impact category & Basins & Delta & $\begin{array}{l}\text { Semi- } \\
\text { arid }\end{array}$ & Total \\
\hline Hydrology & 33 & & 6 & 39 \\
\hline Run-off & 20 & & 4 & 24 \\
\hline Snowmelt & 5 & & & 5 \\
\hline Glacier melt & 3 & & 1 & 4 \\
\hline Glacier retreat & 2 & & & 2 \\
\hline Groundwater & 2 & & 1 & 3 \\
\hline Permafrost & 1 & & & 1 \\
\hline Climate & 15 & & 16 & 31 \\
\hline Precipitation & 4 & & 4 & 8 \\
\hline Temperature & & & 3 & 3 \\
\hline Temperature and precipitation & 4 & & 6 & 10 \\
\hline Evapotranspiration & & & 1 & 1 \\
\hline $\begin{array}{l}\text { Evapotranspiration and } \\
\text { precipitation }\end{array}$ & & & 1 & 1 \\
\hline Drought & & & 1 & 1 \\
\hline Aerosols and glaciers & 2 & & & 2 \\
\hline Community awareness & 5 & & & 5 \\
\hline Ecology & 11 & 4 & 15 & 30 \\
\hline Ecological shifts & 9 & 1 & 8 & 18 \\
\hline Ecosystem degradation & 1 & 3 & 3 & 7 \\
\hline Fisheries & 1 & & & 1 \\
\hline Ungulates & & & 2 & 2 \\
\hline Net primary production & & & 2 & 2 \\
\hline Hazards & 12 & 14 & 1 & 27 \\
\hline Glacial lake outburst flood & 4 & & & 4 \\
\hline Flooding & 3 & 1 & & 4 \\
\hline Sediments & 2 & & & 2 \\
\hline Fire & & & 1 & 1 \\
\hline $\begin{array}{l}\text { Sea-level rise (SLR)—multiple } \\
\text { impacts }\end{array}$ & & 7 & & 7 \\
\hline SLR_-salinity & & 1 & & 1 \\
\hline SLR_measurement & & 1 & & 1 \\
\hline SLR—storm surge & & 1 & & 1 \\
\hline SLR-coastal inundation & & 3 & & 3 \\
\hline Disease-related hazards & 3 & & & 3 \\
\hline Agriculture & 2 & & 10 & 12 \\
\hline Crop yields & 1 & & 5 & 6 \\
\hline Soil carbon & 1 & & & 1 \\
\hline Length of growing period & & & 1 & 1 \\
\hline Livestock & & & 4 & 4 \\
\hline Grand total & 73 & 18 & 48 & 139 \\
\hline
\end{tabular}

glacial lakes, snow and permafrost) in the headwaters of these basins and those concerning changes to run-off in rivers to densely populated areas downstream. In the cryosphere, most publications indicate, to varying degrees, retreating glaciers in most of the Himalayas with the exception of some glaciers in the Karakorum region, which are advancing or stable (e.g. Scherler et al. 2011; Bolch et al. 2012). Miller et al. (2012) report that glacier shrinkage and the relative contribution of glacier melt to the region's river discharge are lower than reported in the AR4. Permafrost degradation and increased snow melt have also being reported on the Tibetan Plateau (the source of many Himalayan rivers) with consequences for downstream flows (Cui and Graf 2009). More generally for India's basins, a reduction in future water yields is projected (Gupta et al. 2011; Gosain et al. 2011). More localised effects downstream include drying up of springs-important water sources in the mid-hills of the Himalaya (Tiwari and Joshi 2012; Tambe et al. 2012). Concerning run-off to the downstream plains, snow and ice melt is extremely important for the Indus Basin, and, but to a lesser degree, for the Brahmaputra basin, but only moderately important for the Ganges (Immerzeel et al. 2010; Miller et al. 2012).

Climate-related impacts, in particular changes in the variability of temperature and precipitation, were the second most common reported. Impacts reported include increasing temperatures particularly in the HKH (Karki et al. 2011) and Tibetan Plateau (Xu et al. 2008). Rainfall trends were less conclusive (Kumar and Jain 2011; Dimri and Dash 2012; Karki et al. 2011; Nandargi and Dhar 2011) although increases in the frequency and intensity of extreme rain were reported (Goswami et al. 2006). An aerosol-related impact was reported concerning the prevalence of black carbon and organic carbon on Tibetan glaciers (Xu et al. 2009a, b), and Himalayan glaciers (Bonasoni et al. 2012) resulting in enhanced melting. Community awareness and perception of climate change were also reported, in a number of the publications for river basins, which generally agreed with observed climatic changes (Biggs and Watmough 2012; Chaudhary and Bawa 2011; Gentle and Maraseni 2012; Manandhar et al. 2011).

The third most common impact category was hazards. Key issues included glacial lake outburst floods (GLOF) in the Himalayas (Gardelle et al. 2011; Shrestha et al. 2010; Chen et al. 2007), increasing sediments loads (Wulf et al. 2012; Lu et al. 2010) and downstream flooding on the plains (Mirza 2011; Immerzeel 2008; Ghosh and Dutta 2012). Malaria and other diseases were also predicted for South Asian river basins (Dhiman et al. 2011; Ebi et al. 2007). Additional impacts focused on various ecological shifts of habitats and species through upward displacement in the Himalaya (Forrest et al. 2012; Telwala et al. 2013; Nasim and Shabbir 2012), in addition to changes in crop yields (Ruane et al. 2013) and soil carbon (Martin et al. 2010). 
Deltas

Studies on deltas were dominated by hazards related to sealevel rise (SLR). Publications mainly focused on the impacts from coastal flooding as a consequence of sealevel rise (SLR), storm surges and projected diminished upstream flows. Ecological impacts, including changes to freshwater-seawater interactions and biotic composition, were mainly covered in publications concerning the Sundarbans in India and Bangladesh (Gopal 2013; Gopal and Chauhan 2006; Mitra et al. 2009) or fisheries (Raha et al. 2012). Saline intrusion of aquifers was mentioned as a potential impact of SLR in a number of studies but was not subject to any detailed analysis.

The global average SLR from 1880 to 2009 is about $21 \mathrm{~cm}$ (Church and White 2011). A study of SLR on the African continent project SLR impacts ranging from 64 to $126 \mathrm{~cm}$ by 2100 (Hinkel et al. 2012). A global study of SLR (Ericson et al. 2006) noted that effective sea-level rise (ESLR) is a net rate, defined by the combination of eustatic sea-level rise, the natural gross rate of fluvial sediment deposition and subsidence, and accelerated subsidence due to groundwater and hydrocarbon extraction and sediment trapping by upstream dams. In all seven African deltas, studied sediment trapping was the dominant factor due to large upstream reservoirs. In Asia, accelerated subsidence due to groundwater extraction was the dominant factor in the Ganges-Brahmaputra delta, whereas sediment trapping dominated in the Indus delta.

A global study of flood risk to cities identified Dhaka and Kolkata with high natural exposure due to a combination of identified risk factors including storm surges, coastal length and river discharge (Balica et al. 2012). River discharge may be a critical factor, since, in the case of Dhaka, modelling of the Brahmaputra River predicts a sharp increase in average and extreme downstream discharges, especially during the monsoon, with a significant threat of flooding in the densely populated floodplain (Immerzeel 2008). Bangladesh and the Nile delta are among the most threatened due to low-lying terrain (Nicholls 2011).

Many of the studies were concerned with using GIS to estimate of the areal extent of inundation [Krishna Godavari delta, Rao et al. (2011); Bangladesh delta, Karim and Mimura (2008)] and a study in the Lagos coastal zone highlights potential overestimates of publically available digital elevation models in comparison to high-precision LiDAR surveys (Van de Sande et al. 2012).

Semi-arid areas

Climate-related impacts were dominant for semi-arid publications. For drylands globally, a warming of greater than 3 degrees Celsius and a $100 \%$ increase in the frequency of extremely warm years is expected by the end of century (Maestre et al. 2012), and increased aridity is expected over most of Africa (Dai 2011) with the associated risks of drought. However, there is general uncertainty over precipitation projections (Maestre et al. 2012) and in particular in the Sahel and West Africa (Giannini 2010; Marshall et al. 2012; Haussmann et al. 2012; Jung and Kunstmann 2007). Terink et al. (2013) project decreases in annual rainfall for most North African countries, especially in southern Egypt, Morocco, and central and coastal Algeria. Observed trends in Southern Africa over the last 30 years are generally towards drier conditions (Batisani and Yarnal 2010). A warming trend for warm days in summer has been observed in the interior peninsular region of India (Dash and Mamgain 2011). Central Asia is projected to become warmer with increased aridity especially in western parts of Turkmenistan, Uzbekistan and Kazakhstan (Lioubimtseva and Henebry 2009).

The next most common impacts, closely related to climate drivers, focused on ecological shifts in rangelands (both to vegetation and animals, mainly ungulates) and impacts to agricultural systems (impacts to livestock and crop yields). In the Sahel, declines in tree density have been observed (Gonzalez et al. 2012), while in Western Africa generally grasslands are projected to expand into desert by an area of 2 million $\mathrm{km}^{2}$ by 2050 (Heubes et al. 2011). In Nambia, irrespective of the direction of precipitation change, Lohmann et al. (2012) project reduced shrub encroachment (an important livestock feed) due to increased mean temperatures, leading to increased costs for supplemental feeding or the need to reduce livestock numbers. In South Africa, models project that a $10 \%$ reduction in mean annual rainfall will lead to a $35 \%$ reduction in livestock numbers (Richardson et al. 2007). In West Africa, projected changes in the timing of rainfall and a reduction in the length of growing period are a particular concern for agricultural production (Sarr 2012). Concerning crops, again notwithstanding uncertainties associated with rainfall projections, impacts on yield are forecast-a systematic review by Knox et al. (2012) report a projected mean change in yield of all crops of minus $8 \%$ by the 2050s in Africa and South Asia. In Africa, generally, reduced food production is forecast if global climate changes to more El Nino like conditions (Stige et al. 2006), with particular implications for maize yields in Southern Africa (Blignaut et al. 2009).

Hydrological impacts were closely related to issues raised under climate concerning precipitation, with the associated uncertainty challenges. Projections of hydrological changes are largely inconclusive for studies reported in West Africa (Druyan 2011), the Nile Basin (Booij et al. 2011) and the Okavango (Hughes et al. 2011). In 
Table 3 Information and knowledge gaps

\begin{tabular}{llll}
\hline Information and knowledge gaps & Basins & Deltas & Semi-arid \\
\hline Lack of observed data & $\checkmark$ & $\checkmark$ & $\checkmark$ \\
Poor hydro-meteorological network & $\checkmark$ & $\checkmark$ & $\checkmark$ \\
Lack of glacier mass-balance data & $\checkmark$ & & \\
Poor glacial lake monitoring & $\checkmark$ & & $\checkmark$ \\
Downscaling for regional climate & $\checkmark$ & \\
models & & \\
Precipitation projections & $\checkmark$ & $\checkmark$ & $\checkmark$ \\
Impacts to groundwater & $\checkmark$ & $\checkmark$ \\
Grazing and ecosystem modelling & & $\checkmark$ & $\checkmark$ \\
Upstream and downstream linkages & $\checkmark$ & $\checkmark$ & $\checkmark$ \\
Tidal gauges & & $\checkmark$ & $\checkmark$ \\
Ecological impacts of SLR & & $\checkmark$
\end{tabular}

Central Asia, the densely populated, arid lowlands depend heavily on the buffering capacity of upstream glacial-fed rivers for irrigation, industry and hydropower (Sorg et al. 2012). In Tajikistan river, discharge is projected to increase due to snow/ice melt to mid-century followed by a decrease in discharge (Kure et al. 2012).

\section{Information and knowledge gaps}

Table 3 lists the main information and knowledge gaps prevalent in each of the hotspot regions. Hotspot-specific issues are described below.

A key information deficit for river basins is a lack of observed data, particularly in the upper reaches, on glacier melting, rainfall and river discharge (Miller et al. 2012; Akhtar et al. 2008; Bocchiola et al. 2011; Rees and Collins 2006; Liu et al. 2012). Climate projections for South Asia, which are also highly variable, have been based on coarse resolution and therefore limit their usefulness for adaptation planning (Wulf et al. 2012; Karki et al. 2011). Uncertainties concerning glaciers are mainly due to a lack of measurements of climatic forcing agents, mass budgets of the glaciers themselves and the use of unsuitable or uncertain data (Bolch et al. 2012). Improving the precipitation and discharge monitoring network, more comprehensive glacier (mass balance) and glacial lake monitoring are key areas that need to be addressed. Given the transboundary nature of this region, greater cooperation on data and knowledge sharing is needed (Karki et al. 2011). There was a general absence of papers dealing with climate change impacts on groundwater and in particular groundwater recharge.

The main driver in the selected publications for studies on deltas was to address the human and economic impacts of coastal flooding and inundation. Ericson et al. (2006) in their study of effective SLR highlight the need for future research to examine both the ocean and terrestrial perspectives, including anthropogenic factors such as groundwater over-abstraction and upstream dams. The ecological repercussions of SLR are generally understudied. Long-term continuous SLR data in Africa are limited compared to other regions (Hinkel et al. 2012), and Africa overall is in need of much better coverage of tidal gauges (Church and White 2011).

In semi-arid regions, climate and hydrological uncertainties dominate and mainly focus on challenges with precipitation projections and are largely due to data deficits, downscaling issues and the fact that global circulation models do not include land cover changes (Marshall et al. 2012; Kenabatho et al. 2012; Terink et al. 2013, Hughes et al. 2011). There is also a need to integrate inter-annual variability with longer-term patterns of climate change (Gaughan and Waylen 2012; Vetter 2009). Long-term monitoring together with new grazing and ecosystem models is needed to better assess climate change impacts on livestock and vegetation (Duncan et al. 2012; Tews et al. 2006; Tietjen and Jeltsch 2007).

\section{Study limitations}

Table 4 provides a list of countries covered by the 139 selected publications. The prevalence of publications from South Asia could reflect the large downstream populations in these river basins, estimated to be over 1.3 billion people (Xu et al. 2009a, b; Immerzeel et al. 2010), as well as the controversy over Himalayan Glaciers in AR4, which may have driven more research in these regions. Studies identified in Africa omitted many of the countries listed in the CARIAA programme (See Ford et al. 2014, for list of countries). The low number of papers on deltas, particularly in Africa, was a concern and prompted a further analysis of the search criteria. The original 1,170 records were revisited and specifically searched for the deltas identified in a companion article by Lwasa (2014) focusing on deltas in these hotspot regions. While no new papers were identified dealing with deltas and biophysical climate impacts, there were some instances in Africa where publications were identified dealing with upstream portions of rivers captured under the semi-arid searches (e.g. Hoffman and Rohde 2011, which deals with changes to riparian vegetation on the Orange river). This tends to indicate a realistic number of peer-reviewed publications dealing specifically with biophysical impacts from climate change in African deltas. However, it also highlights a disconnect between the upstream river basins and downstream deltas and represents a shortcoming of the methodology for African rivers, which were only subject to semi-arid and delta hotspots analysis. This issue may warrant more focused reviews for specific deltas or basins in Africa. This 
Table 4 Number of publications directly covering countries in the CARIAA programme

\begin{tabular}{|c|c|c|c|c|c|}
\hline Region & Country & Basins & Delta & Semi-arid & Total \\
\hline \multirow[t]{5}{*}{ South Asia } & Bangladesh & 4 & 5 & & 9 \\
\hline & Bhutan & 3 & & & 3 \\
\hline & India & 32 & 7 & 4 & 43 \\
\hline & Nepal & 14 & & & 14 \\
\hline & Pakistan & 9 & & & 9 \\
\hline Tibet & China & 9 & & & 9 \\
\hline \multirow[t]{4}{*}{ Central Asia } & Kazakhstan & & & 1 & 1 \\
\hline & Kyrgyzstan & & & 1 & 1 \\
\hline & Tajikistan & & & 1 & 1 \\
\hline & Uzbekistan & & & 1 & 1 \\
\hline \multirow[t]{13}{*}{ Africa } & Algeria & & 1 & & 1 \\
\hline & Angola & & & 2 & 2 \\
\hline & Botswana & & & 5 & 6 \\
\hline & Egypt & & 2 & & 2 \\
\hline & Ghana & & 1 & 1 & 2 \\
\hline & Mali & & & 1 & 1 \\
\hline & Morocco & & 2 & 2 & 4 \\
\hline & Namibia & & & 3 & 3 \\
\hline & Niger & & & 1 & 1 \\
\hline & Nigeria & & 1 & & 1 \\
\hline & South Africa & & & 5 & 5 \\
\hline & Tunisia & & 1 & & 1 \\
\hline & Zambia & & & 1 & 1 \\
\hline
\end{tabular}

Single publications may involve studies in two or more countries. The data in this table are not cumulative (i.e. a publication may deal with one or more countries) and exclude global and continental publications

was less of a problem for South Asian rivers, being subject to river basin and delta hotspots analysis and therefore capturing better upstream-downstream issues. The scale of approach adopted for each publication varied widely. Studies on deltas were obviously focused on the coastal zones. River basin studies tended to follow natural hydrological boundaries. Semi-arid studies had a more regional focus covering two more or countries or large contiguous areas like the Sahel.

There is inevitably bias and error associated with any literature review. One of the objectives of a systematic review is to be transparent and explicit in the methodology so that any inherent bias can be identified. For example, restricting the review to papers since 2006 may introduce bias for particular topic or geographical areas. In their study, attributing biophysical impacts to anthropogenic climate change, Rosenzweig et al. (2008) noted a lack of documented observed changes in a number of regions, including Africa, citing a lack of data and published studies among the reasons for this deficit. Thompson et al. (2010) in their systematic review of climate change and food security in sub-Saharan Africa only identified 14 publications for review and reported on the shortcomings of exclusively using WoK, which may under-represent nonEnglish papers from West and Central Africa. Language may also have been an issue for publications in Central Asia, which was under represented for semi-arid regions. Lioubimtseva et al. (2005) note that most publications on climate and environmental change in Central Asia are in Russian and therefore generally omitted from international researches. Berrang-Ford et al. (2015) note that some systematic reviews address topics that are 'not ready for review'. This is unlikely in this study given the prevalence of climate change research globally; however, the specific research questions could have been disaggregated to better focus on specific geographical regions.

Overall, this review was broadly representative of peerreviewed literature on biophysical impacts from climate change on these hotspot regions. However, there is clearly scope for more focused systematic reviews targeting particular topics and areas within these hotspot regions but also adopting a more expansive suite of multi-lingual literature including, grey literature, books, theses, multilateral and bilateral reports, government reports and consultancy reports.

\section{Discussion}

This systematic review aimed to identify the nature and extent of biophysical impacts from climate change in the three-hotspot regions, to examine their relative significance, and to identify the key knowledge and information gaps to guide future research needs and support adaptation planning. A critical examination of potential bias in the methodology tends to indicate that the review was broadly representative of peer-reviewed literature on biophysical impacts from climate change on these hotspot regions. However, there is scope for more focused systematic reviews adopting a more expansive suite of literature sources.

The biophysical impacts identified in the selected publications varied in nature and extent both between the hotspots and within each hotspot area. Geographical context was an important determinant of the range of biophysical impacts reported for each hotspot. These intrinsic characteristics are a key requirement to establish an area's exposure to various pressures and an important component of vulnerability assessments for particular communities and populations.

In the river basin, studies in South Asia impacts on hydrology, climate and hazards were the main threat from climate change. Studies on the cryosphere and in particular retreating glaciers were an important topic, and some key 
reviews (Scherler et al. 2011; Bolch et al. 2012; Miller et al. 2012) go a significant way to drawing consensus on the behaviour of glaciers in this complex region, while also identifying several key knowledge gaps that need to be addressed. Upstream and downstream linkages were also dominant themes in the river basin studies, although these linkages were not always adequately addressed. The lack of studies examining climate impacts on groundwater recharge downstream was a notable absence. There is clearly an opportunity for more whole-basin approaches, with greater emphasis on upstream-downstream linkages. In this context, greater transboundary cooperation through sharing knowledge and data represents an important challenge and opportunity within this region.

The dominant theme in the delta studies concerned hazards, mainly focussing on the impacts from coastal flooding and inundation as a consequence of sea-level rise, storm surges and projected diminished upstream flows. The concentration of populations and assets in these deltas (Nicholls 2011) is a likely reason for this overwhelming emphasis on coastal inundation. Upstream sediment trapping by dams was a compounding anthropogenic factor in African deltas, while groundwater over-abstraction was a dominant human factor in the many South Asian deltas. Exploration of these seaward and landward factors is an important consideration in climate impact assessments of these deltas and exploration of adaptation options (Ericson et al. 2006, Nicholls 2011). Saline intrusion impacts on ecosystems and saline intrusion of coastal aquifers were generally under represented.

Semi-arid regions were dominated by studies on the impacts concerning climate, ecology and agriculture. Rainfed agriculture in these semi-arid regions of Africa is critical to its development (De Souza et al. 2015), with significant impacts to productivity depending on the timing of delivery of this rain (Boulain et al. 2006). There was a consistent concern in the studies over uncertainty in future precipitation projections and associated hydrological modelling efforts, which pose clear challenges for adaptation planning and represents a key knowledge gap. In response, Haussmann et al. (2012) promote the need for precautionary adaptation strategies that embrace a broad range of possible future outcomes. Knox et al. (2012) highlight the modelling challenges for agriculture noting that ultimately the impact of climate change on crops yields will be a trade-off between yield increases due to elevated carbon dioxide and negative effects due to warmer temperatures, e.g. phenological responses, extreme temperatures and any rainfall limitations to growth. Perhaps more than the two other hotspot regions, semi-arid areas, and in particular their rangelands, highlight the close interplay between climatic events, plant-herbivore interactions and human management interventions (Vetter
2009). Modelling these interactions by linking grazing and ecosystem models also represent an important knowledge gap for semi-arid areas (Tietjen and Jeltsch 2007).

Information gaps common to all regions include a lack of observation data and poor hydro-meteorological monitoring networks. Shared knowledge gaps include climate impacts to groundwater and uncertainty in climate projections, especially for precipitation. Upstream-downstream linkages were also generally not fully investigated or ignored. Addressing these information and knowledge gaps is required to develop a sound understanding of the nature and extent of biophysical impacts in each hotspot region. Such understanding is essential to underpin adaptation strategies that are relevant to each hotspot and sensitive to their geographical context and intrinsic characteristics.

\section{Conclusions}

A range of biophysical impacts from climate change was identified in each of the three hotspot regions-semi-arid zones, mega-deltas and glacial-fed river basins in Africa and Asia. The nature and extent of these impacts varied for each hotspot and were largely determined by the geographical context and intrinsic characteristics of each region. Addressing the knowledge and information gaps on the biophysical impacts of climate change in semi-arid areas, deltas and river basins are essential foundations to support appropriate adaptation planning in these vulnerable regions. Research interventions and programmes developed to address these gaps should aim to:

- Ensure representative coverage of the major natural systems (basins, ecological landscapes and coastal zones), recognising under studied countries and regions, in particular Central Asia and some African countries.

- Encourage the preparation of targeted reviews, ideally systematic reviews, to harness available knowledge and identify gaps for focussed research interventions.

- In Himalayan river basins, develop studies that aim to reduce uncertainty in climate model projections, improve the hydro-meteorological networks, expand standardised glacier and glacial lake monitoring, improve understanding of upstream-downstream linkages, particularly concerning groundwater and hazards, and enhance transboundary cooperation through sharing of knowledge and data.

- In delta areas, develop studies that aim to improve understanding of the ecological consequences of sealevel rise, incorporate the combined perspectives of ocean and terrestrial factors that determine sea-level 
rise, improve understanding of saline intrusion of coastal aquifers and improve the coverage of tidal gauges, particularly in Africa.

- In semi-arid areas, develop studies that aim to reduce uncertainty in precipitation projections, develop enhanced climate models that incorporate land cover changes, develop new grazing and ecosystem models and improve hydro-meteorological networks.

- Overall, encourage studies that address the full range of key biophysical impacts relevant for each hotspot area.

Acknowledgments This research was supported by the United Kingdom's Department for International Development and Canada's International Development Research Centre under their initiative Collaborative Adaptation Research Initiative in Africa and Asia.

\section{References}

Akhtar M, Ahmad N, Booij MJ (2008) The impact of climate change on the water resources of Hindukush-Karakorum-Himalaya region under different glacier coverage scenarios. J Hydrol 355(1-4):148-163

Balica SF, Wright NG, van der Meulen F (2012) A flood vulnerability index for coastal cities and its use in assessing climate change impacts. Nat Hazards 64(1):73-105

Batisani N, Yarnal B (2010) Rainfall variability and trends in semiarid Botswana: implications for climate change adaptation policy. Appl Geogr 30:483-489

Berrang-Ford L, Ford JD, Patterson J (2011) Are we adapting to climate change? Glob Environ Chang 21:25-33

Berrang-Ford L, Pearce T, Ford JD (2015) Systematic review approaches for climate change adaptation research. Reg Environ Change (this issue). doi:10.1007/s10113-014-0708-7

Biggs EM, Watmough GR (2012) A community-level assessment of factors affecting livelihoods in Nawalparasi district, Nepal. J Int Dev 24(2):255-263. doi:10.1002/jid.1844

Bizikova L, Parry JE, Karami J, Echeverria D (2015) Review of key initiatives and approaches to adaptation planning at the national level in semi-arid areas. Reg Environ Change (this issue). doi:10. 1007/s10113-014-0710-0

Blignaut J, Ueckermann L, Aronson J (2009) Agriculture production's sensitivity to changes in climate in South Africa. S Afr J Sci 105:61-68

Bocchiola D, Diolaiuti G, Soncini A, Mihalcea C, D’Agata C, Mayer C, Smiraglia C (2011) Prediction of future hydrological regimes in poorly gauged high altitude basins: the case study of the upper Indus, Pakistan. Hydrol Earth Syst Sci 15(7):2059-2075

Boko M, Niang I, Nyong A, Vogel C, Githeko A, Medany M, OsmanElasha B, Tabo R, Yanda P (2007) Africa. In: Parry ML et al (eds) Climate change 2007: impacts, adaptation and vulnerability. Contributions of working group II to the fourth assessment report of the intergovernmental panel on climate change. Cambridge University Press, Cambridge, pp 433-467

Bolch T, Kulkarni A, Kaab A, Huggel C, Paul F, Cogley JG, Stoffel M (2012) The state and fate of Himalayan glaciers. Science 336(6079):310-314

Bonasoni P, Cristofanelli P, Marinoni A et al (2012) Atmospheric pollution in the hindu kush-himalaya region evidence and implications for the regional climate. Mt Res Dev 32:468-479
Booij MJ, Tollenaar D, van Beek E, Kwadijk JCJ (2011) Simulating impacts of climate change on river discharges in the Nile basin. Phys Chem Earth 36(13):696-709

Boulain N, Cappelaere B, Seguis L, Gignoux J, Peugeot C (2006) Hydrologic and land use impacts on vegetation growth and NPP at the watershed scale in a semi-arid environment. Reg Environ Change 6(3):147-156

Chaudhary P, Bawa KS (2011) Local perceptions of climate change validated by scientific evidence in the Himalayas. Biol Lett 7(5):767-770

Chen X, Cui P, Li Y, Yang Z, Qi Y (2007) Changes in glacial lakes and glaciers of post-1986 in the Poiqu River basin, Nyalam, Xizang (Tibet). Geomorphology 88(3-4):298-311

Church JA, White NJ (2011) Sea-level rise from the late 19th to the early 21st century. Surv Geophys 32(4-5):585-602

Cruz RV, Harasawa H, Lal M, Wu S, Anokhin Y, Punsalmaa B, Honda Y, Jafari M, Li C, Ninh NH (2007) Asia. In: Parry ML et al (eds) Climate change 2007: impacts, adaptation and vulnerability. Contribution of working group II to the fourth assessment report of the intergovernmental panel on climate change. Cambridge University Press, Cambridge, pp 469-506

Cui X, Graf H-F (2009) Recent land cover changes on the Tibetan Plateau: a review. Clim Chang 94(1-2):47-61

Dai A (2011) Drought under global warming: a review. Wiley Interdiscip Rev Clim Chang 2(1):45-65

Dash SK, Mamgain A (2011) Changes in the frequency of different categories of temperature extremes in India. J Appl Meteorol Clim 50(9):1842-1858

De Souza K, Kituyi E, Leone M, Harvey B, Murali KS (2015) Vulnerability to climate change in three hot spots in Africa and Asia: key issues for policy-relevant adaptation and resiliencebuilding research. Reg Environ Change (this issue). doi:10.1007/ s10113-015-0755-8

Dhiman RC, Chavan L, Pant M, Pahwa S (2011) National and regional impacts of climate change on malaria by 2030. Curr Sci 101:372-383

Dimri AP, Dash SK (2012) Wintertime climatic trends in the western Himalayas. Clim Chang 111(3-4):775-800

Druyan LM (2011) Studies of 21st-century precipitation trends over West Africa. Int J Climatol 31(10):1415-1424

Duncan C, Chauvenet ALM, McRae LM, Pettorelli N (2012) Predicting the future impact of droughts on ungulate populations in arid and semi-arid environments. Plos One. doi:10.1371/ journal.pone.0051490

Ebi KL, Woodruff R, von Hildebrand A, Corvalan C (2007) Climate change-related health impacts in the Hindu Kush-Himalayas. Ecohealth 4:264-270

Ericson JP, Vorosmarty CJ, Dingman SL, Ward LG, Meybeck M (2006) Effective sea-level rise and deltas: causes of change and human dimension implications. Glob Planet Chang 50(1-2):63-82

Eriksson M, Jianchu X, Shrestha AB, Vaidya RA, Nepal S, Sandström K (2009) The changing Himalayas: impact of climate change on water resources and livelihoods in the greater Himalayas. ICIMOD, Kathmandu

Ford JD, Berrang-Ford L, Bunce A, Mckay C, Irwin M, Pearce T (2014) The status of climate change adaptation in Africa and Asia. Reg Environ Change (this issue). doi:10.1007/s10113-0140648-2

Forrest JL, Wikramanayake E, Shrestha R, Areendran G, Gyeltshen K, Maheshwari A, Thapa K (2012) Conservation and climate change: assessing the vulnerability of snow leopard habitat to treeline shift in the Himalaya. Biol Conserv 150(1):129-135

Gardelle J, Arnaud Y, Berthier E (2011) Contrasted evolution of glacial lakes along the Hindu Kush Himalaya mountain range between 1990 and 2009. Glob Planet Chang 75(1-2):47-55 
Gaughan AE, Waylen PR (2012) Spatial and temporal precipitation variability in the Okavango-Kwando-Zambezi catchment, southern Africa. J Arid Environ 82:19-30

Gentle P, Maraseni TN (2012) Climate change, poverty and livelihoods: adaptation practices by ruralmountain communities in Nepal. Environ Sci Policy 21:24-34

Ghosh S, Dutta S (2012) Impact of climate change on flood characteristics in Brahmaputra basin using amacro-scale distributed hydrological model. J Earth Syst Sci 121:637-657

Giannini A (2010) Mechanisms of climate change in the semiarid African Sahel: the local view. J Clim 23(3):743-756

Gonzalez P, Tucker CJ, Sy H (2012) Tree density and species decline in the African Sahel attributable to climate. J Arid Environ 78:55-64

Gopal B (2013) Future of wetlands in tropical and subtropical Asia, especially in the face of climate change. Aquat Sci 75(1):39-61

Gopal B, Chauhan M (2006) Biodiversity and its conservation in the Sundarban Mangrove ecosystem. Aquat Sci 68(3):338-354

Gosain AK, Rao S, Arora A (2011) Climate change impact assessment of water resources of India. Curr Sci India 101(3):356-371

Goswami BN, Venugopal V, Sengupta D, Madhusoodanan MS, Xavier PK (2006) Increasing trend of extreme rain events over India in a warming environment. Science 314(5804): 1442-1445

Gupta PK, Panigrahy S, Parihar JS (2011) Impact of climate change on runoff of the major river basins of India using global circulation model (HadCM3) projected data. J Indian Soc Remote Sens 39(3):337-344

Haussmann BIG, Rattunde HF, Weltzien-Rattunde E, Traore PSC, vom Brocke K, Parzies HK (2012) Breeding strategies for adaptation of pearl millet and sorghum to climate variability and change in West Africa. J Agron Crop Sci 198(5):327-339

Heubes J, Kühn I, König K, Wittig R, Zizka G, Hahn K (2011) Modelling biome shifts and tree cover change for 2050 in West Africa. J Biogeogr 38(12):2248-2258

Hinkel J, Brown S, Exner L, Nicholls RJ, Vafeidis AT, Kebede AS (2012) Sea-level rise impacts on Africa and the effects of mitigation and adaptation: an application of DIVA. Reg Environ Change 12(1):207-224

Hoffman MT, Rohde RF (2011) Rivers through time: historical changes in the riparian vegetation of the semi-arid, winter rainfall region of South Africa in response to climate and land use. J Hist Biol 44:59-80

Hughes DA, Kingston DG, Todd MC (2011) Uncertainty in water resources availability in the Okavango River basin as a result of climate change. Hydrol Earth Syst Sci 15(3):931-941

Immerzeel W (2008) Historical trends and future predictions of climate variability in the Brahmaputra basin. Int $\mathrm{J}$ Climatol 28(2):243-254

Immerzeel WW, van Beek LPH, Bierkens MFP (2010) Climate change will affect the Asian water towers. Science 328:1382-1385

IPCC (2007) Climate change 2007: impacts, adaptation and vulnerability. In: Parry ML et al (eds) Contribution of working group II to the fourth assessment report of the intergovernmental panel on climate change. Cambridge University Press, Cambridge

IPCC (2012) Managing the risks of extreme events and disasters to advance climate change adaptation. In: Field CB et al (eds) A special report of working groups I and II of the intergovernmental panel on climate change. Cambridge University Press, Cambridge

Jasco P (2005) As we may search—comparison of major features of the Web of Science, Scopus, and Google Scholar citation-based and citation-enhanced databases. Curr Sci 89:1537-1547

Jung G, Kunstmann H (2007) High-resolution regional climate modeling for the Volta region of West Africa. J Geophys Res Atmos. doi:10.1029/2006JD007951
Karim MF, Mimura N (2008) Impacts of climate change and sea-level rise on cyclonic storm surge floods in Bangladesh. Glob Environ Chang 18(3):490-500

Karki MB, Shrestha AB, Winiger M (2011) Enhancing knowledge management and adaptation capacity for integrated management of water resources in the Indus River Basin. Mt Res Dev 31(3):242-251

Kenabatho PK, Parida BP, Moalafhi DB (2012) The value of largescale climate variables in climate change assessment: the case of Botswana's rainfall. Phys Chem Earth 50-52:64-71

Knox J, Hess T, Daccache A, Wheeler T (2012) Climate change impacts on crop productivity in Africa and South Asia. Environ Res Lett 7:034032

Kumar V, Jain SK (2011) Trends in rainfall amount and number of rainy days in river basins of India (1951-2004). Hydrol Res 42:290-306

Kundzewicz ZW, Mata LJ, Arnell NW, Döll P, Kabat P, Jiménez B, Miller KA, Oki T, Sçen Z, Shiklomanov IA (2007) Freshwater resources and their management. In: Parry ML et al (eds) Climate change 2007: impacts, adaptation and vulnerability. Contribution of working group II to the fourth assessment report of the intergovernmental panel on climate change. Cambridge University Press, Cambridge, pp 173-210

Kure S, Jang S, Ohara N, Kavvas ML, Chen ZQ (2012) Hydrologic impact of regional climate change for the snowfed and glacierfed river basins in the Republic of Tajikistan: hydrological response of flow to climate change. Hydrol Process. doi:10.1002/hyp.9535

Lesnikowski A, Ford J, Berrang-Ford L, Paterson J, Barrera M, Heymann S (2011) Adapting to the health impacts of climate change: a study of UNFCCC Annex I parties. Environ Res Lett 6:044009

Lioubimtseva E, Henebry GM (2009) Climate and environmental change in arid Central Asia: impacts, vulnerability, and adaptations. J Arid Environ 73(11):963-977

Lioubimtseva E, Cole R, Adams JM, Kapustin G (2005) Impacts of climate and land-cover changes in arid lands of Central Asia. J Arid Environ 62:285-308

Liu J, Wang Z, Gong T, Uygen T (2012) Comparative analysis of hydroclimatic changes in glacier-fed rivers in the Tibet- and Bhutan-Himalayas. Quat Int 282:104-112

Lohmann D, Tietjen B, Blaum N, Joubert DF, Jeltsch F (2012) Shifting thresholds and changing degradation patterns: climate change effects on the simulated long-term response of a semiarid savanna to grazing. J Appl Ecol 49(4):814-823

Lu XX, Zhang S, Xu J (2010) Climate change and sediment flux from the Roof of the World. Earth Surf Proc Landf 35(6):732-735

Lwasa S (2014) A systematic review of research on climate change adaptation policy and practice in Africa and South Asia deltas. Reg Environ Change (this issue). doi:10.1007/s10113-0140715-8

Maestre FT, Salguero-Gomez R, Quero JL (2012) It is getting hotter in here: determining and projecting the impacts of global environmental change on drylands. Philos Trans R Soc B 367(1606):3062-3075

Manandhar S, Vogt DS, Perret SR, Kazama F (2011) Adapting cropping systems to climate change in Nepal: a crossregional study of farmers' perception and practices. Reg Environ Change 11(2):335-348

Marshall M, Funk C, Michaelsen J (2012) Examining evapotranspiration trends in Africa. Clim Dyn 38(9-10):1849-1865

Martin D, Lal T, Sachdev CB, Sharma JP (2010) Soil organic carbon storage changes with climate change, landform and land use conditions in Garhwal hills of the Indian Himalayan mountains. Agric Ecosyst Environ 138:64-73

Miller JD, Immerzeel WW, Rees G (2012) Climate change impacts on glacier hydrology and river discharge in the Hindu Kush- 
Himalayas: a synthesis of the scientific basis. Mt Res Dev 32(4):461-467

Mirza MMQ (2011) Climate change, flooding in South Asia and implications. Reg Environ Change 11:S95-S107

Mitra A, Gangopadhyay A, Dube A, Schmidt ACK, Banerjee K (2009) Observed changes in water mass properties in the Indian Sundarbans (northwestern Bay of Bengal) during 1980-2007. Curr Sci India 97(10):1445-1452

Nandargi S, Dhar ON (2011) Extreme rainfall events over the Himalayas between 1871 and 2007. Hydrol Sci J 56(6):930-945

Nasim G, Shabbir A (2012) Shifting herbivory pattern due to climate change: a case study of Himalayan balsam from Pakistan. Pak J Bot 44:63-68

Nicholls RJ (2011) Planning for the impacts of sea level rise. Oceanography 24(2):144-157

Nicholls RJ, Wong PP, Burkett VR, Codignotto JO, Hay JE, McLean RF, Ragoonaden S, Woodroffe CD (2007) Coastal systems and low-lying areas. In: Parry ML et al (eds) Climate change 2007: impacts, adaptation and vulnerability. Contribution of working group II to the fourth assessment report of the intergovernmental panel on climate change. Cambridge University Press, Cambridge, pp 315-356

Pearce T, Ford JD, Duerden F, Smit B, Andrachuk M, Berrang-Ford L et al (2011) Advancing adaptation planning for climate change in the Inuvialuit Settlement Region (ISR): a review and critique. Reg Environ Change 11:1-17

Peel MC, Finlayson BL, McMahon TA (2007) Updated world map of the Köppen-Geiger climate classification. Hydrol Earth Syst Sci 11:1633-1644

Raha A, Das S, Banerjee K, Mitra A (2012) Climate change impacts on Indian Sunderbans: a time series analysis (1924-2008). Biodivers Conserv 21(5):1289-1307

Rao KN, Subraelu P, Kumar KCVN, Demudu G, Malini BH, Ratheesh R, Rajawat AS, Ajai (2011) Climate change and sealevel rise: impact on agriculture along Andhra Pradesh coast-a geomatics analysis. J Ind Soc Remote Sens 39(3):415-422. doi:10.1007/s12524-011-0120-4

Rees HG, Collins DN (2006) Regional differences in response of flow in glacier-fed Himalayan rivers to climatic warming. Hydrol Process 20(10):2157-2169

Richardson FD, Hahn BD, Hoffman MT (2007) Modelling the sustainability and productivity of pastoral systems in the communal areas of Namaqualand. J Arid Environ 70(4):701-717

Rosenzweig C, Neofotis P (2013) Detection and attribution of anthropogenic climate change impacts. Wiley Interdiscip Reviews: Clim Chang 4(2):121-150

Rosenzweig C, Karoly D, Vicarelli M, Neofotis P, Wu Q, Casassa G, Imeson A (2008) Attributing physical and biological impacts to anthropogenic climate change. Nature 453:353-357

Ruane AC, Major DC, Yu WH et al (2013) Multi-factor impact analysis of agricultural production in Bangladesh with climate change. Glob Environ Chang 23:338-350

Sarr B (2012) Present and future climate change in the semi-arid region of West Africa: a crucial input for practical adaptation in agriculture. Atmos Sci Lett 13:108-112

Scherler D, Bookhagen B, Strecker MR (2011) Spatially variable response of Himalayan glaciers to climate change affected by debris cover. Nat Geosci 4(3):156-159

Shrestha AB, Eriksson M, Mool P, Ghimire P, Mishra B, Khanal NR (2010) Glacial lake outburst flood risk assessment of Sun Koshi basin, Nepal. Geomat Nat Hazards Risk 1(2):157-169

Singh SP, Bassignana-Khadka I, Karky BS, Sharma E (2011) Climate change in the Hindu Kush-Himalayas: the state of current knowledge. ICIMOD, Kathmandu
Sorg A, Bolch T, Stoffel M, Solomina O, Beniston M (2012) Climate change impacts on glaciers and runoff in Tien Shan (Central Asia). Nat Clim Chang 2:725-731

Stige LC, Stave J, Chan K-S, Ciannelli L, Pettorelli N, Glantz M, Herren HR, Stenseth NC (2006) The effect of climate variation on agro-pastoral production in Africa. Proc Natl Acad Sci USA 103(9):3049-3053

Sud R, Mishra A, Varma N, Bhadwal S (2015) Adaptation policy and practice in densely populated glacier-fed river basins of South Asia: a systematic review. Reg Environ Change (this issue). doi:10.1007/s10113-014-0711-z

Tambe S, Kharel G, Arrawatia ML, Kulkarni H, Mahamuni K, Ganeriwala AK (2012) Reviving dying springs: climate change adaptation experiments from the Sikkim Himalaya. Mt Res Dev 32(1):62-72

Telwala Y, Brook BW, Manish K, Pandit MK (2013) Climateinduced elevational range shifts and increase in plant species richness in a himalayan biodiversity epicentre. PLOS ONE 8(2):e57103

Terink W, Immerzeel WW, Droogers P (2013) Climate change projections of precipitation and reference evapotranspiration for the Middle East and Northern Africa until 2050. Int J Climatol. doi:10.1002/joc. 3650

Tews J, Esther A, Milton SJ, Jeltsch F (2006) Linking a population model with an ecosystem model: assessing the impact of land use and climate change on savanna shrub cover dynamics. Ecol Model 195(3-4):219-228

Thompson HE, Berrang-Ford L, Ford JD (2010) Climate change and food security in sub-Saharan Africa: a systematic literature review. Sustainability 2:2719-2733

Tietjen B, Jeltsch F (2007) Semi-arid grazing systems and climate change: a survey of present modelling potential and future needs. J Appl Ecol 44(2):425-434

Tiwari PC, Joshi B (2012) Environmental changes and sustainable development of water resources in the Himalayan headwaters of India. Water Resour Manag 26(4):883-907

Tucker J, Few R, Conway D, Daoud M, Oates N, Mtisi S, Matheson S (2014) Social vulnerability in three high-poverty climate change hot spots: What does the climate change literature tell us? Reg Environ Change (this issue). doi:10.1007/s10113-014-0741-6

Van de Sande B, Lansen J, Hoyng C (2012) Sensitivity of coastal flood risk assessments to digital elevation models. Water 4(3):568-579

Vetter S (2009) Drought, change and resilience in South Africa's arid and semi-arid rangelands. S Afr J Sci 105(1-2):29-33

World Bank (2012) Turn down the heat-what a 4 degree celsius warmer world must be avoided. A report for the World Bank by the Potsdam Institute for Climate Impact Research and Climate Analytics. The World Bank

Wulf H, Bookhagen B, Scherler D (2012) Climatic and geologic controls on suspended sediment flux in the Sutlej River Valley, western Himalaya. Hydrol Earth Syst Sci 16(7):2193-2217

Xu ZX, Gong TL, Li JY (2008) Decadal trend of climate in the Tibetan Plateau-regional temperature and precipitation. Hydrol Process 22(16):3056-3065

Xu J, Grumbine RE, Shrestha A et al (2009a) The melting Himalayas: cascading effects of climate change on water, biodiversity, and livelihoods. Conserv Biol 23:520-530

Xu B, Cao J, Hansen J, Yao T, Joswia DR, Wang N, Wu G, Wang M, Zhao H, Yang W, Liu X, He J (2009b) Black soot and the survival of Tibetan glaciers. Proc Natl Acad Sci USA 106(52):22114-22118 